\title{
Bone and Connective Tissue Pathology
}

National Cancer Institute

\section{Source}

National Cancer Institute. Bone and Connective Tissue Pathology. NCI Thesaurus. Code C18660.

The branch of pathology that focuses the causes and nature and effects of diseases of the bone and connective tissues. 